\title{
SEROLOGICAL CHARACTERIZATION OF PRUNE DWARF VIRUS ISOLATES
}

\author{
Elżbieta Paduch-Cichał', Kinga Sala-Rejczak ${ }^{1 *}$, \\ Karolina Mroczkowska ${ }^{1}$, Donato Boscia ${ }^{2}$, Oriana Potere ${ }^{2}$
}

\author{
${ }^{1}$ Department of Plant Pathology, Warsaw University of Life Sciences \\ Nowoursynowska 159, 02-776 Warsaw, Poland \\ ${ }^{2}$ Dipartimento di Protezione delle Piante e Microbiologia Applicata \\ Universitả degli Studi di Bari and CNR, Istituto di Virologia Vegetale, Unit of Bari \\ Via Amendola 165/A, 70126 Bari, Italy
}

Received: April 25, 2011

Accepted: July 4, 2011

\begin{abstract}
Prune dwarf virus (PDV), a worldwide pathogen of stone fruit trees, has many isolates with different biological, serological and molecular properties. Monoclonal antibodies (MAbs) to the Prunus mahaleb isolate of PDV were used to investigate the serological variability of virus isolates, by TAS-ELISA (triple antibody sandwich enzyme-linked immunosorbent assay). The twenty-two PDV isolates from Germany (1), Italy (7), Poland (13) and the USA (1) were characterised against eight single MAbs. The virus showed high serological variability. Analysis of the MAbs reaction allowed for the identification of 13 serogroups.
\end{abstract}

Key words: Prune dwarf virus, MAbs, serogroups, TAS-ELISA

\section{INTRODUCTION}

Prune dwarf virus (PDV) is a member of the Bromoviridae family, genus Ilarvirus. PDV possesses a tripartite genome and isometric to bacilliform particles (Fauquet et al. 2005). Prune dwarf virus is widespread in different stone fruit species (Fulton 1970). Several isolates with different biological, serological and molecular characteristics have been described (Waterworth and Fulton 1964; Paduch-Cichal 2000; Vascova et al. 2000; Fonseca et al. 2005; Ulubas et al. 2009).

Monoclonal antibodies (MAbs) have been produced and used for differentiating PDV isolates. Nine out of 77 MAbs, detected virus isolates from California, Washington, Italy, Bulgaria, Germany, Hungary or France and identified Prunus cerasus L. and Prunus persica Borkh.) serotypes (Jordan et al. 1991). Boari et al. (1997) used eight monoclonal antibodies in the serological characterization of eight PDV isolates by TAS-ELISA (triple antibody sandwich enzyme-linked immunosorbent assay). The results demonstrated that serological differentiation among these virus isolates was possible. The results showed that PDV-B, one of the serotypes identified, seems preferentially associated with almond.

The purpose of our study was to determine the serological variability among 22 PDV isolates from different Prunus species. Classification of these new virus isolates used eight monoclonal antibodies.

\section{MATERIALS AND METHODS}

Twenty-two PDV isolates were collected from virus - infected breaking buds of Prunus amygdalus Batsh., $P$. avium L., P. cerasus L., P. domestica L. and P. persica Borkh. trees. The isolates were from Germany (1), Italy (7), Poland (13) and USA (1) (Table 1).

Eight MAbs (PD-3, PD-6, PD-7, PD-8, PD-9, PD10, PD-11 and PD-12) were used in this study. Boari et al. (1997) used PDV isolate (PDV IAM11) from Prunus mahaleb as antigen to obtain these specific antibodies. Then, eight hybridoma lines were selected and cloned. Monoclonal antibodies were received from Dipartimento di Protezione delle Piante e Microbiologia Applicata (Universitả degli Studi di Bari and CNR, Istituto di Virologia Vegetale,Unit of Bari, Italy).

PDV was detected in different stone fruit species by DAS-ELISA (double antibody sandwich enzyme-linked immunosorbent assay) (Clark and Adams 1977) using a commercial kit of rabbit polyclonal antibodies (PAbs) (LOEWE Biochemica $\mathrm{GmbH}$ ). After the first screening, 22 representative virus isolates were selected based on geographical origin, host species and symptoms. PDVpositive samples were then tested using the TAS-ELISA technique (Spiegel et al. 1996) with a panel of 8 MAbs.

The results were assessed by measuring absorbance at $405 \mathrm{~nm}$. A 405 values above 0.200 were considered positive for PDV. The control values were below this threshold. 
Table 1. Twenty two Prune dwarf virus isolates collected from virus - infected breaking buds of almond, peach, plum, sour cherry and sweet cherry trees, from Germany (1), Italy (7), Poland (13) and the USA (1)

\begin{tabular}{|l|c|c|}
\hline \multicolumn{1}{|c|}{ Isolate } & Original host & Origin of isolate \\
\hline PDV-Almond2 & almond cv. unknown & Italy \\
PDV-PE15-28 & peach cv. unknown & Germany \\
PDV-PE247 & peach cv. Kwiat Majowy & Poland \\
PDV-Plum5 & plum cv. unknow & Italy \\
PDV-PL13 & plum cv. Armed & Poland \\
PDV-PL1-19 & plum cv. unknown & Italy \\
PDV-SO14 & sour cherry Kormed & Poland \\
PDV-SO20SZ1 & sour cherry cv. Royal Burgundy & Poland \\
PDV-SO20SZ3 & sour cherry cv. Royal Burgundy & Poland \\
PDV-SO40 & sour cherry cv. Korund & Poland \\
PDV-SOF15P1 & sour cherry cv. Big Lory & Italy \\
PDV-SOF15P11 & sour cherry cv. Nomene & Italy \\
PDV-SOF17P17 & sour cherry cv. Big Core & Italy \\
PDV-SW6-1 & sweet cherry cv. unknown & Italy \\
PDV-SW7 & sweet cherry cv. Poznańska & Poland \\
PDV-SW9-1 & sweet cherry cv. unknown & USA \\
PDV-SW63 & Prunus avium clone F12/1 & Poland \\
PDV-SW78 & Prunus avium clone F12/1 & Poland \\
PDV-SW145W & sweet cherry cv. Büttnera Czerwona & Poland \\
PDV-SWI-35 & sweet cherry cv. unknown & Poland \\
PDV-SWM1 & sweet cherry cv. Napoleona & Poland \\
PDV-SW-Regina & sweet cherry cv. Regina & Poland \\
\hline
\end{tabular}

\section{RESULTS AND DISCUSSION}

The virus-specific PAbs (polyclonal antibodies) used in this study detected PDV, regardless of the original host or geographic origin. The virus-specific PAbs did not differentiate among the twenty-two PDV isolates (not shown).

Since each MAb recognised a different panel of isolates, it was assumed that the 8 MAbs targeted a different epitope. MAbs 8, 11, 7, 9 and 6 reacted with 18, 17, 16, 14 and 13 isolates, respectively. MAbs 10, 12 and 3 reacted with 8,3 and 1 isolates, respectively. Analysis of the MAbs reaction allowed the identification of 13 serogroups, including the 'PDV-B' of Boari et al. (1997) corresponding to serogroup 12 of this study (Boscia et al. unpublished). None of the eight tested MAbs reacted positively with our PDV-PL13 and PDV-SOF15P1 isolates (Table 2). The variability of isolates from the same host was noted (Table 3). Nine sweet-cherry isolates were assigned to five serogroups. Seven sour-cherry PDV isolates were divided into six different serogroups. Three plum and two peach isolates were grouped into three and two separate serogroups, respectively. One PDV isolate from almond represented subgroup number 4 (positive with MAb PD$8,-9,-11)$, different from serogroup; PDV-B; described by Boari et al. (1997), positive with MAb PD-6, -7, -8, -9, -10, -11 (Boscia et al., unpublished).

Virus variability as related to country of origin is shown in table 4 . There were nine serogroups representing the isolates that occurred in a single country: five in Poland (represented by PDV-SO20SZ1, PDV-SO-
20SZ3, PDV-SW78, PDV-SO14, PDV-SW145W), three in Italy (represented by PDV-Almond2, PDV-Plum5, PDVSO15P11), and one in Germany (represented by PDVPE15-28). The remaining isolate population (13 isolates) contained isolates from more than one country.

Jordan et al. (1991) and Boari et al. (1997) used monoclonal antibodies for the serological differentiation of PDV isolates. The results of these investigations have been confirmed in the study presented in this article. This is the first case of such serological characterization of PDV isolates tested in Poland. In our experiment, the serological characterization of virus isolates was performed by TAS-ELISA. Differentiation among $22 \mathrm{PDV}$ isolates was obtained using eight of MAbs including 3, 6, 7, 8, 9, 10, 11 and 12 in TAS-ELISA. Analysis of the MAbs reaction allowed us to identify 13 serogroups. The serological variability could not be correlated with host species or country of origin. Boari et al. (1997) obtained three different serotype groups, one of which (PDV-B) was only comprised of the two Prunus amygdalus Batsh. isolates. Their examination of 120 samples collected from field-grown PDV-infected Prunus trees (40 of which were almonds), confirmed the natural existence of a wide range of serological PDV variants, which yielded 36 different types of reactants. The PDV-B serotype was detected in 38\% of the almond trees tested, but only in three of the other 86 PDV-infected Prunus plants. The possible prevalence of serogroup PDV-B in almond isolates was not confirmed in this study. 
The serological analysis showed that PDV isolates can be differentiated by a panel of 8 MAbs, as a possible consequence of the occurrence of a large number of serotype specific amino acid substitutions.

Table 2. Serological reaction of twenty-two Prune dwarf virus isolates obtained from infected breaking buds of almond (PDV-Almond2), peach (PDV-PE15-28, PDV-PE247), plum (PDV-Plum5, PDV-PL13, PDV-PL1-19), sour cherry (PDV-SO14, PDVSO20SZ1, PDV-SO20SZ3, PDV-SO40, PDV-SOF15P1, PDV-SOF15P11, PDV-SOF17P17) and sweet cherry (PDV-SW6-1, PDVSW7, PDV-SW9-1, PDV-SW63, PDV-SW78, PDV-SW145W, PDV-SWI-35, PDV-SWM1, PDV-SW-Regina) trees with eight MAbs: PD-3, PD-6, PD-7, PD-8, PD-9, PD-10, PD-11, PD-12 and MAbs mixture (PD-3, PD-6, PD-7, PD-8, PD-9, PD-10, PD-11, PD-12)

\begin{tabular}{|c|c|c|c|c|c|c|c|c|c|c|}
\hline \multirow{2}{*}{ Isolate } & \multicolumn{9}{|c|}{ MAbs } & \multirow{2}{*}{ Serogroup } \\
\hline & 3 & 6 & 7 & 8 & 9 & 10 & 11 & 12 & $\mathrm{M}^{*}$ & \\
\hline PDV-PL13 & - & - & - & - & - & - & - & - & - & 1 \\
\hline PDV-SOF15P1 & - & - & - & - & - & - & - & - & - & 1 \\
\hline PDV-SO20SZ1 & - & - & + & - & - & - & - & - & - & 2 \\
\hline PDV-SO20SZ3 & - & - & + & - & - & - & - & - & + & 2 \\
\hline PDV-SW78 & - & - & - & + & - & - & - & + & + & 3 \\
\hline PDV-Almond2 & - & - & - & + & + & - & + & - & + & 4 \\
\hline PDV-PE15-28 & - & - & + & + & + & - & + & - & + & 5 \\
\hline PDV-Plum5 & - & + & - & + & + & - & + & - & + & 6 \\
\hline PDV-SO14 & - & - & - & + & + & + & + & - & + & 7 \\
\hline PDV-PE247 & - & + & + & + & + & - & + & - & + & 8 \\
\hline PDV-PL1-19 & - & + & + & + & + & - & + & - & + & 8 \\
\hline PDV-SO40 & - & + & + & + & + & - & + & - & + & 8 \\
\hline PDV-SW6-1 & - & + & + & + & + & - & + & - & + & 8 \\
\hline PDV-SW63 & - & + & + & + & + & - & + & - & + & 8 \\
\hline PDV-SW9-1 & - & + & + & + & - & + & + & - & + & 9 \\
\hline PDV-SWI-35 & - & + & + & + & - & + & + & - & + & 9 \\
\hline PDV-SWM1 & - & - & + & + & + & + & + & - & + & 10 \\
\hline PDV-SOF15P11 & + & + & + & + & + & + & + & - & + & 11 \\
\hline PDV-SW7 & - & + & + & + & + & + & + & - & + & 12 \\
\hline PDV-SW-Regina & - & + & + & + & + & + & + & - & + & 12 \\
\hline PDV-SOF17P17 & - & + & + & + & + & + & + & - & + & 12 \\
\hline PDV-SW145W & - & + & + & + & + & + & + & + & + & 13 \\
\hline
\end{tabular}

+ a positive reaction; - a negative reaction; $\mathrm{M}^{*}$ - MAbs (monoclonal antibodies) mixture: PD-3, PD-6, PD-7, PD-8, PD-9, PD-10, PD-11 and PD-12; 1, 2, 3, 4, 5, 6, 7, 8, 9, 10, 11, 12, 13 - number of serogroup

Table 3. Distribution of serogroups within host species. Number of Prune dwarf virus isolates and number of serogroups on the basis of the reaction of each of eight MAbs with twenty-two Prune dwarf virus isolates originating from different Prunus species (almond, peach, plum, sweet- and sour-cherry)

\begin{tabular}{|c|c|c|}
\hline Host species & $\begin{array}{c}\text { Tested isolates } \\
{[\text { No.] }}\end{array}$ & $\begin{array}{c}\text { Identified serogroups } \\
\text { [No.] }\end{array}$ \\
\hline Sweet-cherry & 9 & 5 \\
Sour-cherry & 7 & 6 \\
Plum & 3 & 3 \\
Peach & 2 & 1 \\
Almond & 1 & 2 \\
\hline
\end{tabular}


Table 4. Distribution of PDV serogroups by country of origin. Number of Prune dwarf virus isolates and number of specific serogroups on the basis of the reaction of each of eight MAbs with twenty-two Prune dwarf virus isolates originating from different countries: Poland, Germany, Italy and the USA

\begin{tabular}{|l|c|c|c|c|c|}
\hline \multicolumn{1}{|c|}{ Country } & $\begin{array}{c}\text { Isolates } \\
\text { [No.] }\end{array}$ & $\begin{array}{c}\text { Hosts } \\
\text { [No.] }\end{array}$ & $\begin{array}{c}\text { Identified } \\
\text { serogroups [No.] }\end{array}$ & $\begin{array}{c}\text { Country specific } \\
\text { serogroups [No.] }\end{array}$ & $\begin{array}{c}\text { Isolates in country specific } \\
\text { serogroups [No.] }\end{array}$ \\
\hline Poland & 13 & 4 & 8 & 5 & 5 \\
Italy & 7 & 4 & 6 & 3 & 3 \\
Germany & 1 & 1 & 1 & 1 & 1 \\
USA & 1 & 1 & 1 & none & none \\
\hline
\end{tabular}

\section{ACKNOWLEDGEMENTS}

The generous gift of PDV isolates in different Prunus species by M. Digiaro, W.E. Howell, W. Jelkmann and A. Myrta is gratefully acknowledged.

Research supported by grant N N310 024733 from the Polish Ministry of Science and Higher Education.

\section{REFERENCES}

Boari A., Boscia D., Yurtmen M., Potere O., Turturo C., Savino V. 1997. Production of monoclonal antibodies to prune dwarf ilarvirus and their use in the serological characterisation of almond virus isolate. OEPP/EPPO Bull. 27: 555-556.

Clark M.F., Adams A.N. 1977. Characteristic of the microplate method of enzyme-linked immunosorbent assay for the detection of plant viruses. J. Gen. Virol. 34: 475-483.

Fauquet C.M., Mayo M.A., Maniloff J., Desselberger U., Ball L.A. 2005. Virus Taxonomy. Classifiction and Nomenclature of Viruses. p. 1049-1059. In: Eight Report of the International Committee on the Taxonomy of Viruses. Virology Division International Union of Microbiological Societies, Elsevier Academic Press Amsterdam, Boston, Heidelberg, London, New York, Oxford, Paris, San Diego, San Francisco, Singapore, Sydney, Tokyo, $1162 \mathrm{pp}$.

Fonseca F., Neto J.D., Martins V., Nolasco G. 2005. Genomic variability of Prune dwarf virus as affected by agricultural practice. Arch. Virol. 150: 1607-1619.
Fulton R.W. 1970. Prune dwarf virus. C.M.I./A.A.B. Description of Plant Viruses. No. 19.

Jordan R., Matsumoto T., Hei-Ti H. 1991. Evaluation and application of prune dwarf virus-specific monoclonal antibodies in virus detection and disease diagnosis. Phytopathology 81, p. 1217. (Abstract).

Paduch-Cichal E. 2000. Wielostronna charakterystyka izolatów wirusa nekrotycznej pierścieniowej plamistości wiśni i wirusa karłowatości śliwy. [The Characterization of PNRSV and PDV Isolates]. Fundation: 'Rozwój SGGW', Warsaw, 104 pp. (in Polish).

Speigiel S., Scott S.W., Bowman-Vance V., Tam Y., Galiakparov N.N., Rosner S.A. 1996. Improved detection of prunus necrotic ringspot virus by the polymerase chain reaction. Eur. Biol. 122: 493-500.

Ulubaş Serçe Ç., Ertunç F., Öztrük A. 2009. Identification and genomic variability of Prune dwarf virus variants infecting stone fruit trees in Turkey. J. Phytopathol. 157: 298-305.

Waterworth H.E., Fulton R.W. 1964. Variation among isolates of necrotic ringspot and Prune dwarf viruses isolated from sour cherry. Phytopathology 54: 1155-1160.

Vaškova D, Pertzik K., Špak J. 2000. Molecular variability of the capsid protein of the Prune dwarf virus. Eur. J. Plant Pathol. 106: 573-580. 